\title{
Menumbuhkan Jiwa Sherlock Holmes Seorang Calon Akuntan
}

\author{
Eko Febri Lusiono ${ }^{\mathrm{a}, *}$ dan Eliza Noviriani ${ }^{\mathrm{b}}$ \\ a Prodi Akuntansi Sektor Publik, Politeknik Negeri Sambas, ekodelisa2004@gmail.com, Indonesia \\ bProdi Akuntansi Sektor Publik, Politeknik Negeri Sambas, Indonesia
}

\begin{abstract}
Abstrak. Penelitian ini disebut sebagai proses pembebasan pendidikan akuntansi karena pendidikan akuntansi cenderung kaku dan terlalu berorientasi pada buku teks. Peneliti menyajikan sebuah metode pembelajaran yang diadaptasi dari penelitian Chabrak dan Craig (2013) dengan film "Sherlock Holmes: the Game of Death"sebagai media pendukung. Dalam proses ini, peserta didik berada dalam nuansa "giving" melalui imajinasi, perilaku disonansi serta berpikir kritis. Dengan menggunakan pendekatan fenomenologi transendental, jiwa Sherlock Holmes (seharusnya) di tubuh akuntan adalah temuan tak terbantahkan dalam proses pembebasan.
\end{abstract}

Keywords: pembebasan, pendidikan akuntansi, fenomenologi, disonansi kognitif, akuntan

\begin{abstract}
This research is referred to as the process of liberation of accounting education caused accounting education tends to be rigid and oriented on textbooks. The researcher presents a method of learning adapted from Chabrak and Craig (2013) research with the film "Sherlock Holmes: the Game of Death" as a supporting media. In process, learners are in the nuance of "giving" through imagination, dissonance behavior and critical thinking. Using the transcendental phenomenology approach, the soul of Sherlock Holmes (supposedly) in the accountant's body is an indisputable finding in the liberation process.
\end{abstract}

Keywords: liberation, accounting education, fenomenology, cognitive disonance, accountant

\section{Pendahuluan}

Pendidikan telah mengarahkan kita pada kulit (bukan pada substansi), mengajak kita untuk melihat keluar (bukan ke jati diri), menyeret kita pada kalkulasi rasional (bukan pada intuisi), dan mengajarkan kita untuk berorientasi pada hasil (dengan mengabaikan proses) (Triyuwono, 2010). Education is the most powerful weapon which you can use to change the world $^{l}$. Kutipan ini kiranya tidak mungkin dan bahkan sama sekali tidak pantas untuk dibantah. Terlebih Finlandia telah membuktikan bahwa pendidikan adalah salah satu penunjang keberhasilan transformasi negara tersebut dari ekonomi tradisional menuju ekonomi modern dalam kurun waktu yang tergolong singkat
(Sahlberg, 2009). Namun merujuk pada petikan ungkapan Triyuwono (2010) di atas dan bila berkaca pada kualitas pendidikan di Indonesia saat ini dapat dikatakan bahwa pendidikan masih kekurangan "daya" nya jika dibandingkan dengan negara lain. Sebagaimana diungkapkan oleh Menteri Keuangan Republik Indonesia:

"Indonesia membelanjakan 20 persen APBN untuk pendidikan, terlihat sama dengan Vietnam. Tapi hasilnya Indonesia skor di 64-68, dan Vietnam itu di 80 -an. Sama-sama 20 persen untuk pendidikan, tapi hasilnya sangat berbeda." (www.metrotvnews.com).

Terpuruknya kualitas pendidikan di Indonesia ini secara tidak langsung merupakan cerminan rendahnya kualitas pembelajaran. Poin utamanya berada pada

\footnotetext{
*Corresponding author. E-mail: ekodelisa2004@gmail.com

${ }^{1}$ Diucapkan oleh Nelson Rolihlahla Mandela atau lebih dikenal dengan nama Nelson Mandela adalah seorang revolusioner antiapartheid dan politisi Afrika Selatan yang menjabat sebagai Presiden Afrika Selatan sejak tahun 1994 hingga 1999 (www.nelsonmandela.org).
} 
tenaga pendidik ${ }^{2}$. Sebagai agen pembelajaran, tenaga pendidik merupakan kunci utama keberhasilan pendidikan (Mukani, 2016). Karena sebagaimana ditekankan oleh Asy'ari (1995), di-gugu dan di-tiru adalah sebuah profesi mulia untuk mendidik generasi penerus bangsa yang diharuskan memiliki ilmu syariat yang bagus, mencintai berbagai macam ilmu, serta dapat dijadikan panutan. Oleh karenanya, tidak mengherankan jika kemudian mereka menjadi pihak yang dianggap paling bertanggung jawab terhadap baik buruknya kualitas pendidikan.

Hakikat pendidikan sebenarnya merupakan salah satu media untuk melakukan transfer pengetahuan dan perilaku dalam realitas yang sesuai dengan nilai-nilai sosial masyarakat (Mulawarman, 2006). Mengingat hal itu, maka diperlukan sistem pengajaran yang tidak hanya memusatkan perhatian pada tataran "penjejalan" teori-teori dan berpegang pada asumsi pada dasarnya "manusia itu bodoh"," tapi juga memberikan "exercise" guna melatih peserta didik agar aktif berpikir kritis.

Ironisnya, keadaan semacam ini nyatanya turut terjadi dalam pendidikan tinggi akuntansi di Indonesia. Sistem pendidikan akuntansi dirasa masih mengalami kendala substansial (Mulawarman, 2006). Kendala tersebut tentunya akan berdampak pada kualitas peserta didik yang dihasilkan. Pada akhirnya, ketika peserta didik terjun ke lingkungan masyarakat untuk memainkan perannya (sebagai seorang akuntan) realitas akuntansi yang terbentuk berdasarkan pendidikan yang mereka dapatkan sebelumnya (Morgan, 1988).

Metode pendidikan akuntansi dapat dikatakan masih berorientasi pada unsur "taking" daripada "giving". Peserta didik dimanifestasikan sebagai objek yang hanya berhak untuk menerima segala bentuk materi pengetahuan. Kita ambil contoh, ilmu akuntansi yang mereka dapatkan selama menempuh pendidikan tinggi

\footnotetext{
${ }^{2}$ Peneliti mengkhususkan dengan sebutan tenaga pendidik bukan tenaga pengajar. Karena, walaupun sepintas terlihat sama namun ada perbedaan yang cukup besar diantara keduanya. Dalam Kamus Besar Bahasa Indonesia (KBBI), ajar artinya petunjuk kepada orang supaya diketahui (diturut) sedangkan didik berarti memelihara dan memberi latihan (ajaran, tuntunan, pimpinan) mengenai akhlak dan kecerdasan pikiran. Berdasarkan hal tersebut, menurut peneliti tenaga pendidik memiliki peran yang lebih dominan dibandingkan tenaga pengajar (lihat Undang-Undang Nomor 20 Tahun 2003).

${ }^{3}$ Ungkapan "manusia bodoh" dicetuskan oleh Triyuwono (2010) bermakna bahwa peserta didik dianggap sebagai obyek pasif yang hanya diam dan menerima "kucuran" ilmu pengetahuan dari para dosen.

${ }^{4}$ Peneliti menggunakan kata "kita" untuk merujuk pada peran sebagai tenaga pendidik yaitu dosen. Terdapat penekanan pada subjektifitas dalam penelitian. Hal ini diperbolehkan karena berbeda dengan penelitian positivistik yang menjunjung tinggi objektifitas,
}

baik dalam tataran teori maupun praktek berkiblat pada ilmu barat. Apakah ini salah? Tentu saja tidak, tapi jangan sampai hal ini membuat kita ${ }^{4}$ terkesan "tahu beres" dengan sekedar "menjejalkan pesan" kepada peserta didik untuk mereka pahami. Jika di kemudian hari mereka berada di posisi yang sama, keadaan ini akan menjadi sebuah lingkaran setan yang terus berulang dan tak berujung. Akhirnya, proses pendidikan tinggi hanya akan menghasilkan akuntanakuntan yang sangat kalkulatif, sistematis, berbicara dengan data, skeptis dan logis yang merupakan karakteristik otak kiri (Soeherman, 2011).

Sebenarnya reformasi pendidikan akuntansi dan upaya terkait untuk memperluas batas-batas disiplin akuntansi telah menduduki pikiran reformis selama beberapa tahun terakhir (Fouche, 2013; Boyce dan Greer, 2013). Bukan tanpa alasan, hal ini dikarenakan terlalu bergantungnya pendidikan akuntansi dengan buku-buku teks (Irvin, 1995; Kamayanti, 2012) yang pada umumnya berkaitan dengan transaksi keuangan (Wilkin dan Collier, 2009) sehingga tidak ada nuansa pembelajaran yang merangsang pemaknaan ilmu akuntansi pada pikiran terlebih hati ${ }^{5}$ peserta didik. Padahal, mereka memiliki tiga paket kecerdasan (intelektual, emosional, spiritual) yang jika diberdayakan akan menghasilkan pemikiran-pemikiran yang melampaui (hyper).

Lantas, bagaimana mewujudkan sistem pendidikan akuntansi dengan warna yang berbeda? Poin pentingnya, metode pendidikan akuntansi selain menghasilkan kemampuan korporasi paling tidak dapat "menghidupkan" potensi kepemimpinan, tanggung jawab, kepercayaan diri, independensi serta kemampuan komunikasi dan pengambilan keputusan (Riccio dan Sekata, 1999) sekaligus menstimulus sisi kesadaran etis ${ }^{6}$, tidak hanya berpusat pada kebutuhan pangsa pasar dengan pendekatan positivistik ${ }^{7}$ (Mulawarman, 2006; James, 2008; Triyuwono, 2010)

paradigm non positivistik tidak terlepas dari unsur subjektifitas peneliti (Creswell, 2007)

${ }^{5}$ Akuntansi adalah alat laksana pisau, jika digunakan secara tepat maka akan memberikan manfaat, namun bila digunakan dengan tidak semestinya boleh jadi menimbulkan mudharat. Untuk itulah hati diperlukan guna mengontrol pikiran dalam pengimplementasian ilmu akuntansi.

6 Sulitnya menerapkan perilaku etis salah satunya dikarenakan banyak tekanan yang diterima oleh auditor baik dari sisi individu maupun struktur organisasi dan masyarakat (lihat Noviriani et al 2017). Bahkan Trevino dan Brown (2004) sampai membuat pernyataan bahwa being ethical is not simple!

7 Para ahli mengklasifikasikan paradigma yang dapat digunakan sebagai pendekatan penelitian dalam beberapa kategori, diantaranya Burrell dan Morgan (1979) merumuskan empat paradigma yaitu paradigma positivistik, interpretif, radikal humanis dan radikal strukturalis. Chua (1986) menyederhanakan pembagian paradigma 
dan terjebak pada kekakuan buku teks (Kamayanti, 2012).

Kurangnya reformasi dalam pendidikan akuntansi yang berlangsung lama dan hampir universal menunjukkan bahwa pendekatan personal dari tenaga pendidik dibutuhkan untuk memajukan agenda reformasi tersebut (Carmona, 2013). Dengan menggunakan metode yang tepat, peserta didik tidak hanya sekedar menerima curahan ilmu dengan kemampuan untuk menjelaskan (to explain) dan memprediksi (to predict) teori maupun praktik akuntansi yang seringkali identik dengan angka-angka (sisi intelektual), tetapi lebih dari itu mereka dapat mengembangkan kapasitas pemikiran pada ranah diantaranya ${ }^{8}$ (a) mengapa hal itu terjadi? (b) apa yang menyebabkan hal itu terjadi? (c) bagaimana terjadinya hal tersebut? (d) apakah hal itu harus/boleh terjadi? (e) jika tidak, bagaimana teori/praktik akuntansi seharusnya? (sisi emosional dan spiritual) serta banyak lagi pengembangan pemikiran mencengangkan yang akan muncul.

Semua berpulang kembali pada peran tenaga pendidik dalam menerapkan sistem pembelajaran. Tenaga pendidik memiliki tantangan untuk meningkatkan keahlian peserta didik seiring dengan kemajuan dunia, sebagaimana Fouche (2013) mengungkapkan:

"The changing demands on the skill requirements regarding entry-level accounting reflects directly on the educational system. Lecturers themselves face similar challenges to broaden their skills in order to assist learners to do the same. Lecturers also face challenges of facilitating learners in the process of acquiring these skills in such a manner that they could apply them in the real world."

Chabrak dan Craig (2013) menyatakan bahwa peserta didik harus didorong untuk membayangkan budaya dan wacana lain guna menantang ideologi yang berlaku serta membayangkan bahwa model akuntansi alternatif (selain dalam teori dominan) dapat digunakan dalam praktek akuntansi. Pernyataan ini dibuktikan oleh riset yang dilakukan Byrne dan Flood (2004) di mana peserta didik dengan pembelajaran berpusat pada konstruksi dan pemaknaan dapat dengan mudah mengadopsi pendekatan yang lebih mendalam.

tersebut menjadi tiga paradigma yaitu paradigma positivistik, interpretif dan kritis. Pendekatan positivistik ini menganggap akuntansi bebas nilai (value free) sehingga keilmiahan sebuah ilmu hanya dipandang dari sisi scientific method sehingga unsur-unsur lain yang dianggap tidak rasional seperti rasa dan intusi dianggap unsur yang dapat mencederai keilmiahan sebuah ilmu (Triyuwono, 2010).
Peserta didik perlu merasakan sensasi "giving", Berimajinasi... mengeksplorasi ide-ide liar, merasakan "terjun langsung" ke dalam dunia akuntansi, memaknai sebuah "pesan" kemudian menemukan solusi pemecahan masalah baik teori maupun praktek, merasakan pemikiran mereka digunakan dalam pembelajaran akuntansi. Soeherman (2011) menyebutnya dengan Six Senses:

"Kemajuan zaman menuntut akuntan untuk mengoptimalkan kemampuan otak kanan diantaranya kemampuan desain, bercerita, bersimfoni, menciptakan kesenangan, berempati dan memaknai sesuatu atau disebut Six Sense."

Untuk itulah, penelitian ini mencoba membangkitkan sensasi "giving" dan kompetensi six senses yang dimiliki peserta didik. Dengan mengadopsi pemikiran Chabrak dan Craig (2013) dalam metode pembelajaran, peneliti mendorong peserta didik untuk berimajinasi, membangkitkan disonansi kognitif dan menemukan intisari pembelajaran melalui proses berpikir kritis.

Di lain hal, dalam dunia riset khususnya di Indonesia pendidikan akuntansi mulai menjadi bintang yang bersinar. Hal ini terlihat dari berbagai macam konferensi/simposium maupun publikasi ilmiah yang menempatkan pendidikan akuntansi menjadi salah satu bidang kajian. Popularitas pendidikan akuntansi sudah dapat disejajarkan dengan bidang kajian lain yang memang merupakan bidang mainstream dalam akuntansi, sebut saja diantaranya Akuntansi Keuangan dan Pasar Modal. Realita ini menandakan muncul kesadaran tentang perlunya perubahan dalam sistem pendidikan akuntansi di Indonesia yang selama ini berjalan. Dengan berlandaskan pada kesamaan pemikiran, masing-masing peneliti menawarkan solusi alternatif untuk mengatasi "kekakuan" sistem pendidikan akuntansi hingga tercetus pernyataan pendidikan akuntansi di Indonesia perlu dibebaskan! (Mulawarman, 2006; Triyuwono, 2010; Soeherman, 2011; Kamayanti, 2012; Mulia, 2012; Ekasari, 2014; Aneswari dan Musmini, 2017).

Sistem pendidikan akuntansi seharusnya tidak hanya menitikberatkan pada kecerdasan intelektual semata. Hal ini terbukti karena Mulia (2012) berhasil menggali sisi kecerdasan emosional dan spiritual mahasiswa

\footnotetext{
${ }^{8}$ Pemikiran tidak terkukung sebatas menerima fakta (what, when, who) lebih daripada itu dapat menjelaskan fakta dari sisi luar hingga sisi terdalam (why, how) serta (how it should be) dengan berlandaskan pada kecerdasan emosional dan spiritual.
} 
akuntansi untuk menghasilkan kompetensi yang utuh. Sedangkan Soeherman (2011) melalui tulisannya mengingatkan para civitas akademika akuntansi tentang perubahan peran pendidikan akuntansi dan profesi akuntan di tengah pergeseran era menuju era konseptual yang menuntut kemampuan otak kanan. Pada tataran konstruksi atas metode pembelajaran, Mulawarman (2006) merumuskan delapan konsepsi pembelajaran $^{9}$ dan Triyuwono (2010) mencetuskan pentingnya membangkitkan "Mata Ketiga" yaitu kecerdasan spiritual dalam kurikulum pendidikan akuntansi dengan olah rasa dan olah batin di mana olah rasa meliputi rasa kasih sayang, rasa amanah, rasa bersih, rasa adil dan rasa syukur, sedangkan olah batin meliputi merasakan kehadiran Tuhan dan berguru kepada Tuhan. Selanjutnya, Kamayanti (2012) melakukan proses dialogis sebagai upaya pembebasan pikiran peserta didik yang selama ini terkukung dengan memasukkan nilai-nilai Pancasila.

Sekali lagi, peneliti merasa turut terpanggil dalam barisan "pembebas pendidikan akuntansi" ini. Berbeda dengan penelitian-penelitian sebelumnya, peneliti menyajikan sebuah proses pembebasan dengan menggunakan metode pembelajaran berdasarkan penelitian Chabrak dan Craig (2013). Sebuah film berperan sebagai media pendukung dalam proses ini.

Intinya, tulisan ini merekam proses "giving" pada beberapa pertemuan tatap muka dalam kegiatan pembelajaran pada mata kuliah Pengauditan bagi mahasiswa vokasi jurusan Akuntansi di semester genap tahun ajaran 2015-2016. Proses "giving" menggunakan metode yang menggabungkan unsur akal, batin dan rasa melalui imajinasi, perilaku disonansi serta berpikir kritis untuk kemudian hasilnya dituangkan dengan pendekatan fenomenologi. Melalui untaian tulisan, pembaca menikmati esensi pemikiran peserta didik mengenai jiwa Sherlock Holmes (seharusnya) di tubuh seorang akuntan.

\footnotetext{
9 Konstruksi pembelajaran yang melampaui terdiri dari: A. The increase of knowledge, B. Memorizing, C. Acquisitions of facts, procedures, etc., which can be retained and/or used in practice, $D$. Abstraction of meaning, E. An interpretative process aimed at the understanding of reality, $F$. Changing as a person, G. A self awareness with intuitive process dan $H$. An obedience activity with spiritual way. Tiga konsepsi pertama (A-C) merefleksikan pandangan reproduktif pembelajaran (reproductive view of learning), sedangkan tiga konsepsi berikutnya (D-F) merefleksikan pandangan
}

\section{Kajian Literatur}

\section{GIVING: Imajinasi, Disonansi Kognitif dan Berpikir Kritis}

Leon Festinger (1957) mengeluarkan teori disonansi kognitif yang menggambarkan konsep disonansi kognitif sebagai keadaan psikologis di mana kognisi individu saling bertentangan. Teori Festinger mendalilkan bahwa individu, bila dihadapkan dengan bukti yang bertentangan dengan pandangan atau keyakinan akan mengalami disonansi kognitif (Basnett, 2013). Sementara itu, Boyce dan Greer (2012) mengungkapkan:

\section{"Cognitive dissonance is the theoretical construct used to explain psychological responses to information that conflicts with individuals' pre-existing personal beliefs or understandings. As general rule, consistency is preferred to dissonance and when confronted with inconsistencies with beliefs, people will tend to enact changes that restore a state of consonance."}

Dari pernyataan di atas, disonansi kognitif menjelaskan respon psikologis atas informasi yang bertentangan dengan keyakinan pribadi atau pemahaman seseorang. Konsistensi lebih diinginkan dibandingkan disonansi dan ketika dihadapkan pada inkonsistensi (dengan kepercayaan), seseorang cenderung akan memberlakukan perubahan yang mengembalikan keadaan pada posisi konsonan (semula).

Festinger mengemukakan empat sumber disonansi, yaitu inkonsistensi logis, nilai-nilai budaya, pendapat umum, dan pengalaman masa lalu (Metin dan Camgoz, 2011). Artinya, disonansi mungkin timbul setidaknya dari satu di antara sumber-sumber tersebut. Dalam keberadaan disonansi inilah individu termotivasi untuk mengurangi disonansi dan menghindari situasi yang dapat meningkatkannya. Ilustrasi sederhananya adalah seorang perokok yang telah mengetahui bahwa merokok berdampak buruk bagi kesehatan dapat mengubah perilakunya (dengan berhenti merokok), mengubah pengetahuannya tentang efek merokok

konstruktif pembelajaran (constructive view of learning). Dua konsep terakhir adalah proses pencerahan-pembebasan dalam konsep tazkiyah dengan melakukan proses pembebasan (emansipasi) yang mengasah intuisi yang berkesadaran (G) dan dilanjutkan dengan ketundukan dan penyerahan diri secara total kepada Sang Pencipta (H) (Lihat Mulawarman, 2006) 
(beranggapan merokok tidak berbahaya) atau menambahkan sumber kognitif baru yang sesuai dengan fakta merokok (berbahaya jika merokok saat berlalu lintas).

Dalam tulisannya, Chabrak dan Craig (2013) menyajikan sebuah tontonan yang menggambarkan tentang keruntuhan Enron. Disonansi kognitif dari peserta didik muncul ketika mereka mengetahui bahwa salah satu penyebab jatuhnya perusahaan sekaliber Enron adalah sifat greedy yang identik dengan sistem kapitalis dewasa ini. Hal ini berasal dari keyakinan mereka bahwasanya greedy merupakan sifat yang kontradiktif dengan nilai-nilai budaya.

Sementara itu, berpikir merupakan proses alamiah setiap manusia. Tetapi, jika dibiarkan begitu saja seringkali menjadi bias, terdistorsi, parsial, kurang informatif dan akan menutup potensi sehingga keunggulan dalam pemikiran harus diberdayakan (Scriven dan Paul, 2004). Menurut Samli (2011), imajinasi adalah awal dari berpikir kritis. Dengan berimajinasi, peserta didik dapat memberdayakan kemampuan berpikir mereka agar senantiasa berpikir kritis. Berpikir kritis pada hakikatnya memiliki makna yang sederhana, yaitu kemampuan untuk menganalisis dan mengevaluasi informasi diantaranya merumuskan permasalahan dengan jelas, mengumpulkan dan menilai informasi yang relevan, menggunakan ide abstrak, berpikiran terbuka, dan berkomunikasi secara efektif dengan yang lain (Duron et al, 2006).

Chabrak dan Craig (2013) mendorong peserta didik untuk keluar dari stigma "pemikir pasif" yang senantiasa melihat akuntansi hanya dari perspektif satu arah yaitu ilmu yang bersumber dari tenaga pendidik. Dalam transformasi sebagai "pemikir aktif" dengan berlandaskan nilai moral dan etika, untuk mengatasi keadaan inkonsistensi peserta didik mencetuskan pemikiran bahwa sistem kapitalis seharusnya ditiadakan dalam kurikulum pendidikan akuntansi ${ }^{10}$.

Diperlukan film untuk mewujudkan proses "giving" pada pembelajaran akuntansi. Mengapa? film adalah media yang sangat baik untuk memberi makna pada teori maupun konsep (Champoux, 2007; Moskovich dan Sharf, 2012). Seakan mendukung argumen Irvin

10 Akuntansi dan kapitalisme adalah dua hal yang tidak terpisahkan. Jika mengetikkan keyword "Accounting and Capitalism" maka akan terlihat berbagai macam ulasan yang membahas keterkaitan antar keduanya. Yang paling mengejutkan adalah pernyataan bahwa cikal bakal kapitalisme berasal dari sistem pembukuan berpasangan (double entry bookkeeping) (Yamey, 1949). ${ }^{11}$ Di rilis pada tahun 2009, Sherlock Holmes adalah film aksi-misteri yang didasarkan pada karakter dengan nama yang sama oleh Sir Arthur Conan Doyle. Film ini disutradarai oleh Guy Ritchie yang berkisah tentang penyelidikan kasus oleh seorang detektif bernama
(1995) dan Kamayanti (2012), Champoux (2007) menyatakan bahwa efek visual dari film dapat menyampaikan pesan lebih baik daripada buku cetak:

"The visual and auditory effects of great films can convey a message better than printed or spoken words. Selected scenes from 12 Angry Men will show students the meaning of conflict episodes, and its concepts, more effectively than a text book or lecture...."

Seperti halnya Chabrak dan Craig (2013) yang menggunakan film "Enron: The Smartest Guys in the Room", peneliti memanfaatkan film berjudul "Sherlock Holmes: the Game of Death" "11 dalam upaya pembebasan.

\section{Metode Penelitian}

\section{Merekam GIVING dengan Pendekatan Fenomenologi}

Hasil dari proses pembebasan ini dituangkan dalam sebuah tulisan dengan berlandaskan pada paradigma interpretif. Paradigma ini juga disebut dengan interaksional subjektif (Mancintosh, 1994). Paradigma interpretif lebih menekankan pada makna atau interpretasi seseorang terhadap sebuah simbol. Penelitian interpretif tidak menempatkan objektivitas sebagai sesuatu yang mutlak, tapi menyadari bahwa untuk memperoleh pemahaman, subjektivitas para pelaku harus digali sedalam mungkin. Hal ini memungkinkan terjadinya trade off antara objektivitas dan kedalaman temuan penelitian (Efferin dan Yuliawati, 2004). Artinya, semakin dalam temuan penelitian maka akan semakin subjektif temuan tersebut.

Menggunakan fenomenologi transendental ${ }^{12}$, peneliti ingin mengeksplorasi fenomena berdasarkan kesadaran individu (Noviriani et al, 2017). Perlu di ingat, fenomenologi transendental "mengharamkan" keterlibatan peneliti dengan mentransfer ide, pengetahuan teori, hipotesis maupun informasi tertentu. Dalam hal ini, peneliti (sebagai tenaga

Sherlock Holmes beserta seorang dokter sahabat karib nya John Watson (www.imdb.com).

12 Dalam fenomenologi transendental segala informasi bebas dari persepsi sehingga semuanya dianggap murni berasal dari informan. Utamanya, ber pedoman pada konsep Husserl, yakni epoche (bracketing) dimana membutuhkan eliminasi atas prasangka atau ego dan pengetahuan terdahulu peneliti sehingga fenomena bebas campur tangan peneliti dan murni pengalaman dari informan (Moustakas, 1994). 
pendidik) tidak menyampaikan "pesan" yang berkaitan dengan tugas dan tanggung jawab, kode etik akuntan maupun standar audit selama proses pembebasan ${ }^{13}$. Harapannya, peneliti dapat menggali esensi jiwa seorang akuntan murni berdasarkan pemikiran dari peserta didik yang bersumber dari pengalamannya dalam proses pembebasan.

Beberapa tahapan sistematis analisis data dalam fenomenologi transendental dikemukakan oleh Moustakas (1994) dalam (Creswell, 2007). Tahapantahapan ini dilakukan untuk mendapatkan esensi fenomena yang mengalir dan runtut dalam satu kesatuan sehingga dapat diinterpretasikan dengan baik:

"1) Building on the data from the first and second research questions, data analysts go through the data (e.g., interview transcriptions) and highlight "significant statements," sentences, or quotes that provide an understanding of how the participants experienced the phenomenon (horizonalization). Next, the researcher develops clusters of meaning from these significant statements into themes. 2) These significant statements and themes are then used to write a description of what the participants experienced (textural description). They are also used to write a description of the context or setting that influenced how the participants experienced the phenomenon, called imaginative variation or structural description. Moustakas (1994) adds a further step: Researchers also write about their own experiences and the context and situations that have influenced their experiences. 3) From the structural and textural descriptions, the researcher then writes a composite description that presents the essence" of the phenomenon, called the essential, invariant structure (or essence). Primarily this passage focuses on the common experiences of the participants."

Sumber data utama berupa kata-kata dan tindakan diperoleh melalui pengamatan (observasi), wawancara serta dialog dengan para informan yang merupakan peserta didik pada mata kuliah pengauditan. Wawancara yang dilakukan adalah jenis wawancara kelompok (group interview). Hal ini dikarenakan menurut Frey dan Fontana (1991) wawancara kelompok memiliki potensi besar untuk penelitian sosial karena peneliti dapat menggunakan wawancara kelompok untuk mengefisiensikan penggunaan sumber

\footnotetext{
${ }^{13}$ Proses pembebasan dilaksanakan di pertemuan kedua semester genap tahun ajaran 2015-2016 pada mata kuliah pengauditan. Pada pertemuan pertama peneliti memberikan materi pengenalan auditing dan auditor.
}

daya dan sebagai sarana untuk menambah informasi terkait perilaku atau peristiwa sosial. Proses tersebut berlangsung di kelas dalam kurun waktu 3 kali jadwal perkuliahan yang direkam dan didokumentasikan. Selain itu, peneliti menggunakan sumber tertulis berupa hasil "giving 14 " yang ditulis oleh peserta didik untuk merefleksikan bagaimana seharusnya jiwa seorang akuntan.

Dikarenakan film memiliki durasi yang tergolong panjang yaitu sekitar 130 menit maka diperlukan waktu 2 kali pertemuan untuk menyelesaikan tontonan. Peneliti juga meminta mahasiswa untuk menonton film tersebut di rumah masing-masing agar lebih fokus sehingga pemaknaan mereka terhadap film untuk memahami perilaku akuntan semakin baik. Dengan demikian, alur proses pembebasan yang dapat dibentuk adalah seperti yang terlihat dalam skema 1 terlampir.

\section{Pembahasan}

Awal Kisah Untuk Membebaskan

"Hari ini kita nggak usah belajar, kalian nonton film saja. Belajar pun kalian ngantuk semua". Begitu kalimat yang keluar dari mulut saya ketika memasuki kelas. Suasana kelas yang agak riuh mendadak senyap. Terdengar bisik-bisik beberapa mahasiswa yang berasumsi bahwa saya marah, di pojok lain sejumlah mahasiswa berusaha mengingat kesalahan apa yang mereka perbuat.

"Kok diam?" sambung saya. "Maafkan kami Bu..." cetus Sapta seorang mahasiswi yang terkenal aktif di kelas. "Lo, kalian kan saya ajak nonton film, seharusnya ucapkan terima kasih bukan maaf" ucap saya lagi yang semakin menambah keheningan kelas. "Kami mau belajar Bu" giliran Harry yang menjawab. Dengan cepat saya berkata, "Saya sedang tidak mau ngajar Harry. Saya mau kalian menonton film ini lalu kalian analogikan dengan mata kuliah kita. Bebas! kerahkan daya imajinasi kalian, berpikirlah kritis."

"Film apa Bu?" mereka mulai antusias. "Sherlock Holmes: the Game of Death", tutur saya sambil menyalakan laptop. Terdengar suara dari barisan belakang yang berasal dari Yudhi, "Berarti kita nanti hubungkan film dengan audit gitu ye Bu?" Dan, suara pun menggema seantaro kelas "Iyeee Yudhi!" bersamaan dengan dimulainya film. Enjoy!

14 Tulisan dari peserta didik yang berisi pemikiran mereka. Pengumpulan data dengan telaah dokumen berguna untuk mengungkap realitas sosial dalam sebuah dokumen (Creswell, 2007) 


\section{Sensasi GIVING yang Mewujudkan Pemahaman Baru}

Di hari kedua menonton.

"Oke, filmnya sudah selesai. Saya juga sudah menginstruksikan kalian untuk nonton film ini di rumah masing-masing. Sekarang, saya minta temukan benang merah antara film tadi dengan mata kuliah. Kalian boleh menyoroti apa saja terkait pengauditan, entah itu metode audit, standar, proses bahkan auditor sekali pun ${ }^{15}$. Saya tidak meminta kalian untuk googling... melihat buku. Jangan takut, berimajinasilah kemudian tuliskan." jelas saya panjang lebar. "Saya beri kalian waktu, 30 menit..."

Setelah 30 menit, seluruh tulisan dikumpulkan dan saya memilih beberapa hasil tulisan mahasiswa. Sejumlah 29 orang yang ada di kelas mengaitkan film dengan topik yang bervariasi. Namun saya tertarik pada 11 orang mahasiswa, hampir separuh jumlah mahasiswa yang mengangkat tokoh Sherlock Holmes untuk kemudian memanifestasikannya sebagai seorang akuntan. Dari 11 orang tersebut, 8 mahasiswa terpilih untuk membacakan hasil analisisnya. Rizkie Amalia adalah orang pertama:

"Nah, tugas Sherlock Holmes sama dengan tugas auditor. Seorang auditor harus jeli dan telaten dalam memeriksa area audit. Auditor tidak boleh hanya berpaku pada audit checklist dan standar."

"Sebentar-sebentar... Terus kalau tidak berpaku pada audit checklist dan standar pedomannya dari mana?" potong saya.

Auditor harus memeriksa lingkungan kerja juga $\mathrm{Bu}$, komitmen dan kesungguhan mereka dalam memperbaiki sistem seperti apa. Jadi, auditor tidak boleh gegabah dalam melaporkan temuan."

Berikutnya, Jean Clara Yolanda Silitonga:

“...Demikian pula dalam proses pengauditan, auditor harus mengumpulkan data atau bukti-bukti dari transaksi atau kejadian yang telah dilakukan suatu perusahaan maupun pihak ketiga dari kejadian tersebut, sampai bukti tersebut dianggap kompeten atau cukup. Selain itu, sikap atau mentalitas seorang Sherlock Holmes juga patut dicontoh, sikapnya yang tidak mudah menyerah dan tidak terpengaruh terhadap pihak eksternal yang dapat mengecohkan penyelidikan yang dilakukannya sampai

15 Tahap krusial karena peneliti berusaha untuk tidak menyampaikan materi. Pengetahuan peserta didik baru sampai pada tahap benar-benar terkuak kebenaran dari kejadian tersebut. Pada akhirnya, tindakan Sherlock Holmes ketika mengungkap kejadian tersebut juga patut dicontoh seorang auditor. Sikap yang objektif, apa adanya menceritakan awal kejadian sampai bukti-bukti yang didapatkannya yang juga menguatkan kebenaran dari kejadian tersebut, tindakan Sherlock Holmes yang tetap mengungkapkan kebenarannya, dan tidak merekayasa kejadian tersebut, sampai pada pemberian statement bahwa Lord Blackwood melakukan suatu rekayasa ilmu hitam. Demikian pula seorang auditor harus memiliki sikap objektif, apa adanya, dan tetap mengungkapkan kebenaran yang sesungguhnya, dan harus memberikan pernyataan atau pendapat yang sesuai dengan fakta atau realita dari hasil penyelidikan yang telah dilakukannya."

Giliran Rustriyadi yang membacakan tulisannya:

“...Sherlock Holmes memiliki keahlian yang baik seperti penyamaran, pengumpulan bukti-bukti serta pengamatan yang sangat baik. Keahlian yang cukup pula harus dimiliki oleh seorang auditor dalam mengaudit atau memeriksa laporan keuangan. Setiap bukti yang dikumpulkan berdasarkan hasil pengamatan yang teliti. Seperti pengumpulan bukti dari beberapa kejadian kematian yang dicurigai bahwa Lord Blackwood yang menjadi pelaku utama dari semua kejadian tersebut. Data-data yang dikumpulkan Holmes dapat dikatakan akurat, karena melakukan suatu penelitian atau observasi pada tempat kejadian, serta mengumpulkan beberapa bukti lain sampai bukti tersebut dianggap cukup untuk mengungkap suatu kasus. Hal tersebut harus dimiliki juga oleh seorang auditor, harus mengumpulkan data-data yang cukup, bukti yang kompeten, akurat sampai dirasa bukti tersebut cukup untuk mengungkap suatu kejadiaan atau kasus."

Menyusul Cynthia Pratikasari:

“...Karakter Holmes dapat kita kaitkan dengan karakter seorang auditor yaitu akurat, detail, logis dan gigih..."

Harry Chandra Saputra selanjutnya:

"Holmes dan auditor tidak bisa memecahkan kasus kalau tidak ada data data."

Vina Lestari mengungkapkan: 
“...Yang paling pertama yang harus ada dalam diri seorang auditor ialah perencanaan dan analisis titik serang. Maksudnya, seorang auditor harus tahu apa yang akan dilakukannya nanti saat proses mengaudit dan juga mampu menganalisis laporan yang harus ia audit serta dapat menganalisis bukti-bukti yang sudah ia dapatkan nantinya. Kedua, melakukan pengamatan dan mengumpulkan bukti. Ketiga, mengumpulkan datanya dengan turun langsung ke lapangan. Keempat, auditor harus baik dan kompak bekerjasama seperti hanya Holmes dan Watson."

Menurut Wulanjani Endah Astuti:

“...Setelah kasus terpecahkan, Holmes juga membuat pelaporan yaitu berupa pernyataan yang bisa dikatakan sulit dipahami oleh publik, sehingga ia membuat berbagai pernyataan yang logis untuk menjelaskan berbagai kejanggalan yang ada agar kasus yang telah terpecahkan dapat dipahami kronologinya oleh khalayak."

Badriyah mendapatkan giliran terakhir:

“...Terpercaya, saat Watson menyatakan kehebatan seseorang dalam ilmu supranatural, Holmes tidak mempercayainya, menurutnya suatu kesalahan besar untuk berteori sebelum memiliki data karena sesungguhnya teori akan sesuai dengan fakta bukannya fakta yang menyesuaikan teori. Humoris, meskipun Holmes seorang detektif handal namun ia tidak sombong, bisa bergaul dengan baik contohnya saat ia dipenjara karena menenggelamkan kapal, Holmes bisa berbaur dengan para tahanan lain. Tidak terpengaruh dengan uang, saat Holmes diminta oleh Sir Thomas Rodrum untuk melenyapkan Blackwood, Holmes tidak bersedia untuk dibayar karena Holmes melakukan hal tersebut karena keingintahuannya. Disiplin, meskipun Sir Thomas telah mati namun Holmes tetap menyelidiki Blackwood dan berusaha mengumpulkan bukti sedetail dan sebanyak mungkin. Gigih, saat ia, Watson dan Irene terjebak di ruang pemotongan daging Holmes terus berusaha agar mereka bisa keluar dari ruangan itu dengan selamat. Tenang, di ruang pemotongan daging Holmes tetap tenang. Total, saat melakukan penyelidikan Holmes sangat total dan bersungguh-sungguh bahkan ia mempelajari metode Blackwood. Terukur, Holmes berhasil menyelamatkan diri dengan cara menciptakan asap untuk menghalangi pandangan Coward..."

\footnotetext{
${ }^{16}$ Di pertemuan pertama peneliti membahas kasus Enron

${ }_{17}$ Proses disonansi kognitif. Individu merasa bahwa apa yang terjadi tidak sesuai dengan keyakinan (Akuntan belum bersikap etis)
}

Serta merta seluruh mahasiswa bertepuk tangan setelah teman-temannya membacakan hasil tulisan mereka. "Good Job! Ini yang saya maksud, menyenangkan kan? Kalian bisa mendalami sosok Holmes dan mengubahnya menjadi akuntan. Akuntan yang sebenar-benarnya akuntan. Dari mana semua ini? Imajinasi! Apa jadinya kalau kalian takut membayangkan, sudah berpikir ah nggak masuk akal, nggak mungkin tulisan ini tercipta. Nah, sekarang saya tanya, perlu kah sikap-sikap itu diterapkan auditor?" Tutur saya. "Perluuu..." ujar mereka. "Sudahkan diterapkan?" tanya saya lagi. "Kalau ada manipulasi kayak yang Ibu ceritakan yang Enron ${ }^{16} t u$ berarti belum lah ye Bu?" ucap Harry. Dengan tersenyum saya berujar "Jadi, apakah yang harus auditor lakukan?" "Memiliki sikap seperti Sherlock Holmes ketika melakukan proses pengauditan Bu." ${ }^{17}$ tutup Jean.

\section{Temuan: Jiwa Sherlock Holmes (Seharusnya) di Tubuh Akuntan}

Proses pembebasan mengadaptasi metode yang dikemukakan oleh Chabrak dan Craig (2013) ini membuahkan pemikiran peserta didik yang berasal dari imajinasi dan pikiran kritis. Dengan menyelami pikiran mereka, esensi bagaimana seharusnya jiwa seorang akuntan terungkap. Lebih luas, jiwa seorang akuntan ini terbagi menjadi sikap umum, sikap yang harus dimiliki ketika melaksanakan tugas di lapangan serta sikap saat membuat laporan. Berikut peneliti sajikan dalam Tabel 1 di bawah ini:

Tabel 1

Jiwa Seorang Akuntan

\begin{tabular}{|c|c|c|}
\hline Sikap umum & Sikap saat di lapangan & $\begin{array}{c}\text { Sikap membuat } \\
\text { laporan }\end{array}$ \\
\hline $\begin{array}{l}\text { - Objektif } \\
\text { - Keahlian yang } \\
\text { cukup } \\
\text { - Akurat } \\
\text { - Detail } \\
\text { - Logis } \\
\text { - Gigih } \\
\text { - Perencanaan dan } \\
\text { analisis titik serang } \\
\text { - Terpercaya } \\
\text { - Humoris } \\
\text { - Tidak terpengaruh } \\
\text { dengan uang } \\
\text { - Disiplin } \\
\text { - Tenang } \\
\text { - Total }\end{array}$ & $\begin{array}{l}\text { - Memeriksa lingkungan } \\
\text { kerja. } \\
\text { - Jeli dan telaten dalam } \\
\text { memeriksa area audit. } \\
\text { - Tidak boleh hanya } \\
\text { berpaku pada audit } \\
\text { checklist dan standar. } \\
\text { - Mengumpulkan data } \\
\text { atau bukti-bukti dari } \\
\text { transaksi atau kejadian } \\
\text { yang telah dilakukan } \\
\text { suatu perusahaan } \\
\text { maupun pihak ketiga, } \\
\text { sampai bukti tersebut } \\
\text { dianggap kompeten } \\
\text { atau cukup. }\end{array}$ & $\begin{array}{l}\text { - Membuat } \\
\text { berbagai } \\
\text { pernyataan yang } \\
\text { logis untuk } \\
\text { menjelaskan } \\
\text { berbagai } \\
\text { kejanggalan yang } \\
\text { ada agar kasus } \\
\text { yang telah } \\
\text { terpecahkan dapat } \\
\text { dipahami } \\
\text { kronologinya oleh } \\
\text { khalayak. } \\
\text { - Tidak boleh } \\
\text { gegabah dalam }\end{array}$ \\
\hline
\end{tabular}

sehingga hal tersebut harus diubah ke "jalan” yang sebenarnya (sikap etis). 


\begin{tabular}{lll}
\hline- Terukur & Melakukan & melaporkan \\
& pengamatan. & temuan. \\
$\bullet$ & Mengumpulkan & \\
& datanya dengan turun & \\
& langsung ke lapangan. & \\
$\bullet$ & Tidak bisa & \\
& memecahkan kasus & \\
& kalau tidak ada data. & \\
&
\end{tabular}

Temuan di atas sebenarnya mencakup kode etik akuntan yang meliputi integritas, objektivitas, kompetensi serta sikap cermat dan kehati-hatian professional, kerahasiaan dan perilaku professional ${ }^{18}$ maupun standar audit yang terdiri dari standar umum, standar pekerjaan lapangan dan standar pelaporan ${ }^{19}$. Namun, peserta didik mengungkapkannya dengan bahasa yang sesuai dengan pemahaman mereka ${ }^{20}$ sebut saja "tidak terpengaruh dengan uang", sebenarnya ini menekankan pada sisi independensi. Selain itu, pernyataan "akurat, detail, logis, gigih, perencanaan, terpercaya, disiplin, tenang dan terukur" merupakan bentuk-bentuk perilaku professional yang seharusnya diimplementasikan akuntan sesuai dengan yang diatur dalam kode etik. Yang menarik adalah, Badriyah mengungkapkan kata "humoris". Humoris di sini bukan berarti bahwa akuntan harus selalu bercanda tapi lebih kepada sikap santai dan tidak kaku (tanpa mengurangi profesionalitas) tentunya. Seperti pernyataannya:

“...meskipun Holmes seorang detektif handal namun ia tidak sombong, bisa bergaul dengan baik contohnya saat ia dipenjara karena menenggelamkan kapal, Holmes bisa berbaur dengan para tahanan lain..."

Sikap seperti ini dibutuhkan karena kadangkala akuntan merupakan "momok menakutkan" bagi perusahaan terperiksa. Sebagaimana temuan Noviriani et al (2017) bahwa objek pemeriksaan (obrik) memiliki ketakutan tersendiri ketika diperiksa oleh auditor inspektorat. Selama ini obrik menganggap inspektorat hanya mencari-cari kesalahan, dapat "disuap" dan laksana tukang jahit hingga anggapan bahwa hasil pemeriksaan bisa "dipesan" sesuai dengan yang diinginkan. Dengan adanya sikap yang lebih bersahabat, maka diharapkan akan terjalin kerjasama yang baik sehingga hasil yang didapatkan juga maksimal.

Pada temuan terkait sikap auditor di lapangan, peneliti ingin menyoroti pernyataan Rizkie Amalia

\footnotetext{
${ }^{18}$ Lihat kode etik Akuntan professional IAI

${ }^{19}$ Lihat standar audit.
}

"Tidak boleh hanya berpaku pada audit checklist dan standar". Menurut peneliti, hal ini tidak menyalahi ketentuan, karena yang dimaksud oleh peserta didik sebenarnya adalah pentingnya skeptisisme bagi akuntan. Artinya, akuntan dapat melihat kejanggalankejanggalan di luar audit checklist yang telah disusun. Sementara itu, dari sisi sikap saat pelaporan, yang menarik adalah pemikiran Wulanjani yaitu "membuat berbagai pernyataan yang logis untuk menjelaskan berbagai kejanggalan yang ada agar kasus yang telah terpecahkan dapat dipahami kronologinya oleh khalayak". Dengan sikap demikian, pembaca laporan (dalam hal ini manajemen) dapat memahami isi dari laporan audit.

\section{Kesimpulan}

\section{Sebuah Akhir dan Keterbatasan}

Jiwa Sherlock Holmes (seharusnya) di tubuh akuntan adalah temuan tak terbantahkan dalam proses pembebasan ini. Dari keseluruhan tersebut, kita bisa menarik kesimpulan bahwa peserta didik bisa mencipta! Imajinasi dan pikiran kritis mereka menghasilkan desain jiwa seorang akuntan yang begitu kompleks. Penelitian ini "hanya" delapan orang peserta didik, bayangkan bagaimana pemikiran yang terbentuk jika empat puluh orang atau bahkan lebih yang terlibat? Bukan tidak mungkin ke depannya pemikiranpemikiran mereka inilah yang kemudian digunakan sebagai dasar bertindak oleh "kita". Semoga....

Walaupun demikian, keterbatasan penelitian ini terletak pada konsistensi penerapan metode pembelajaran yang dijalankan. Peneliti mengakui, dibutuhkan waktu yang tidak sedikit untuk menggali pemikiran-pemikiran peserta didik, sementara materi perkuliahan yang harus disampaikan dalam satu semester demikian banyak. Hal ini menjadi tantangan tersendiri bagi pendidik. Namun, jika melihat hasil mencengangkan yang dapat diperoleh, usaha maksimal tentunya tidak akan terbuang sia-sia. Sekarang, tergantung komitmen "kita" sebagai pendidik. Maukah anda bergabung dalam barisan "pembebas pendidikan akuntansi"?

\footnotetext{
${ }^{20}$ Kesadaran individu yang kemudian "ditangkap" menggunakan fenomenologi transcendental.
} 


\section{References}

Aneswari, Yuyung Rizka dan Lucy Sri Musmini (2017). Quo Vadis Pancasila Dalam Pendidikan Akuntansi Di Indonesia?. Jurnal Akuntansi Multiparadigma, Volume 8, Nomor 1, April 2017, p 149165.

Asy'ari, Muhammad Hasyim (1995). Adab al 'Alim wa al Muta'allim. Maktabah at Turats al Islamy. Jombang.

Boyce, Gordon dan Susan Greer (2012). More Than Imagination: Making Social and Critical Accounting Real. Critical Perspectives on Accounting 24(2) p 105-112.

Burrell, G \& G. Morgan (1979). Sociological Paradigms and Organisational Analysis: Elements of the Sociology of Corporate Life. Heinemann. London

Byrne, Marann dan Barbara Flood (2004). Exploring the conceptions of learning of accounting students. Accounting Education 13 (Supplement 1), p 25-37.

Chabrak, Nihel dan Rusell Craig (2013). Student imaginings, cognitive dissonance and critical thinking. Critical Perspectives on Accounting 24(2) p 91-104.

Champoux, Joseph E (2007). Film as a Teaching Resource. Journal of Management Inquiry Vol 8, Issue 2, 1999.

Chua, Wai Fong (1986). Radical Developments in Accounting Thought. The Accounting Review LXI (4): 601-32.

Creswell, J. W (2007). Qualitative Inquiry and Research Design: Choosing Among Five Approaches. $2^{\text {nd }}$ ed. Sage Publications, Inc. United State of America.

Duron, Robert, Barbara Limbach \& Wendy Waugh (2006). Critical Thinking Framework for Any Dicipline. International Journal of Teaching and Learning in Higher Education. Volume 17, Number 2, p 160-166.

Ekasari, Kurnia. (2014). Rehumanisasi Pendidikan Akuntansi Melalui Pendekatan Epistemologi 3ling. Jurnal Akuntansi Multiparadigma, Volume 5, Nomor 2, Agustus 2014, p 273-286.

Efferin, S Stevanus \& T Yuliawati (2004). Metode Penelitian Akuntansi Mengungkap Fenomena dengan Pendekatan Kuantitatif dan Kualitatif. Edisi Pertama. Penerbit Graha Ilmu. Yogyakarta.

Frey, James H dan Andrea Fontana (1991). The group interview in social research. The Social Science Journal Volume 28, Issue 2, 1991, p 175-187.

Fouche, J P. (2013). A Renewed Call for Change in Accounting Education Practices. International Journal of Educational Sciences Vol 5.
James, Kieran (2008). A Critical Theory and Postmodernist Approach to The Teaching of Accounting Theory. Critical Perspective on Accounting. Vol 19. p 643- 676.

Kamayanti, Ari (2012). Cinta: Tindakan Berkesadaran Akuntan (Pendekatan Dialogis Dalam Pendidikan Akuntansi). Simposium Nasional Akuntansi XII. p 1-25.

Metin, Irem \& Selin Metin Camgoz (2011). The Advances in the History of Cognitive Dissonance Theory. International Journal of Humanities and Social Science Vol. 1 No. 6.

Moustakas, C (1994). Phenomenological Research Methods. Sage Publications. United States of America.Mukani, 2016).

Mulia, Annisa Sekar (2012). Mengungkap Pemahaman Tentang Akuntansi dari Kecerdasan Emosional, Spiritual Dan Sosial Mahasiswa. Jurnal Akuntansi Multiparadigma, Volume 3, Nomor 3, Desember 2012, p 441-456.

Mulawarman, Aji Dedi (2006). Pendidikan Akuntansi Berbasis Cinta: Lepas dari Hegemoni Korporasi Menuju Pendidikan yang Memberdayakan dan Konsepsi Pembelajaran Yang Melampaui. Ekuitas Vol.12 No.2 Juni 2008 p 142-158.

Noviriani, Eliza, Unti Ludigdo dan Zaki Baridwan (2017). Studi Fenomenologi atas Dilema Etis Auditor Internal Pemerintah. Simposium Nasional Akuntansi Vokasi VI. p 1-20.

Sahlberg, Pasi (2009). A Short History of Educational Reform in Finland. Journal of Education Policy, 221 p 147-171.

Samli, A C (2011). From Imagination to Creativity. From Imagination to Innovation: New Product Development for Quality of Life, DOI 10.1007/978-1-4614-0854-3_2, Springer Science + Business Media, LLC.

Scriven, M \& Paul R (2004). The Critical Thinking Community. Diakses tanggal 10 April 2018 dari http://www.criticalthinki ng.org/aboutCT/definingCT.shtml

Soeherman, Bonnie (2011). Tinjauan Kontemplatif Peranan Akuntan di Era Konseptual: Perimbangan Kembali Kehakikian Otak Belahan Kiri dan Kanan. Jurnal Akuntansi Multiparadigma, Volume 2, Nomor 2, Agustus 2011, p 279-293.

Trevino dan Brown (2007). Ethical Leadership: A Review and Future Direction. The Leadership Quarterly, pp: 595-616.

Triyuwono, Iwan Tri (2010). "Mata Ketiga": Se Laen, Sang Pembebas Sistem Pendidikan Tinggi Akuntansi. Jurnal Akuntansi Multiparadigma, Vol. 1 No. 1 April 2010.

Wilkin L Carla dan Philip A Collier (2009). A Problem Based Aprroach to Accounting Education: A Pagmatic Appraisal of A Technologically Enabled Solution." Vol 5 Issue 2, p 49-67.

Yamey, B S (1949). Scientific Bookeping and the Rise of Capitalism. The Economic History Review Second Series Vol 1 Nos 2 \& 3. 
Lampiran 1

Skema 1

Alur Proses Pembebasan

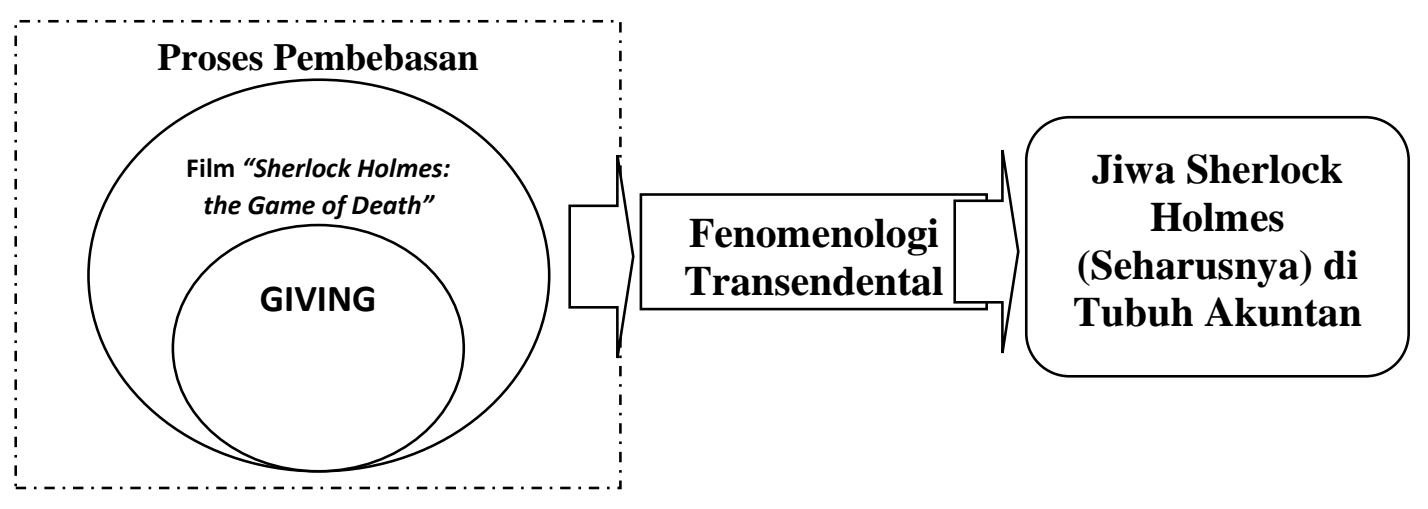

